\title{
Characterization of Pure and Undefined Petroleum Fractions of Messla and Sarir Crude Oils of Libya Using Correlation Models
}

Ibrahim M. Abou El Lei ${ }^{*_{1}}$, Nuri M. Triki ${ }^{2}$, Khaled M. Mezughi ${ }^{3}$

${ }^{*}$ Department of Petroleum Engineering, Faculty of Engineering, Tobruk University, Tobruk, Libya ${ }^{2}$ Department of Mechanical Engineering, Faculty of Engineering, Sabratha University, Sabratha, Libya

${ }^{3}$ Department of Chemical Engineering, Faculty of Petroleum and Gas, Zawia University, Zawia, Libya

\section{Article Info}

Volume 7, Issue 6

Page Number: 194-211

Publication Issue :

November-December-2020

\section{Article History}

Accepted : 01 Nov 2020

Published : 10 Nov 2020

\section{ABSTRACT}

Knowing the physical properties of hydrocarbons and petroleum fractions is essential for designing most crude oil production and refining processes. Several correlations, called group contribution methods, have been proposed in the literature to assess these parameters and have been used extensively. The majority frequent correlations reported in the literature, where it is generally accepted in the petroleum industry, are used to describe unspecified fractions of oil. The only input parameters required are specific gravity and normal boiling point or molecular weight. Calculated properties include: normal boiling point $\left(\mathrm{T}_{\mathrm{b}}\right)$, Molecular weight $(\mathrm{Mw})$, critical properties for instance critical pressure $\left(\mathrm{P}_{c}\right)$, critical temperature $\left(\mathrm{T}_{c}\right)$, critical volume $\left(\mathrm{V}_{c}\right)$ and acentric factor $(\omega)$, as well as other parameters including Watson factor $(K)$, and compressibility factor $\left(Z_{c}\right)$. In this approach, $x$ samples of petroleum fractions of Messla and Sarir crude oils of Arabian Gulf Oil Company, Libya have been collected. A quantity of characterization technique of untainted and unknown petroleum fractions have been presented to foresee the physical properties of these petroleum fractions. Correlations for characterizing non-specific petroleum fractions suppose precise seriousness and boiling point as input parameters. These correlations are Twu Correlations, Cavett Correlations, Kesler-Lee Correlations and Riazi-Daubert Correlations. The physical properties of the compounds in terms of specific gravity $(\gamma)$ and $\left(\mathrm{T}_{\mathrm{b}}\right)$ were shown on the algorithm and the correlation models for the auxiliary acids were corrected in this study. The considerations addressed revealed that there is no significant difference between the correlation models and the results obtained and it appears to be very close to the similar published data of the cited authors. Keywords: Correlation Models, Petroleum Fractions, Physical Properties, Hydrocarbons Characterization.

Copyright: (C) the author(s), publisher and licensee Technoscience Academy. This is an open-access article distributed under the terms of the Creative Commons Attribution Non-Commercial License, which permits unrestricted noncommercial use, distribution, and reproduction in any medium, provided the original work is properly cited 


\section{INTRODUCTION}

Petroleum restrains severe variety of organic functionality and molecular size. Crude oils and refined petroleum products, in particular, are largely composed of hydrocarbons, which are chemicals made up of only hydrogen and carbon in different molecular configurations. Crude oils include hundreds of diverse hydrocarbons and other organic and inorganic stuffs counting atoms of sulfur, nitrogen, and oxygen, in addition to metals for instance iron, vanadium, nickel, and chromium [7], [15]. On the other hand, Petroleum is a fluid, gaseous, or constant natural solid mixture, mainly composed of hydrocarbon fractions, to facilitate accrues in underground tanks. Since a generic expression with the purpose of is constantly changing over time [1], it is generally lengthy and costly. Therefore, one frequently searches for empirical correlations, derived from the input of two or more characterizing factor [10]. Knowledge of the physical, chemical and thermodynamic properties of petroleum mixtures play an important role in the design and operation of almost every part of equipment in the petroleum industry. In chemical processes, it is needed to know these data to improve the efficiency of equipment and optimize time and energy consumption. Some physical properties of mixtures are easily measurable, such as specific gravity, while other properties such as the critical properties and enthalpy of vaporization cannot be measured easily [5].

The constituents of a natural reservoir fluid form an almost continuous hydrocarbon spectrum from the lightest, (methane), throughout intermediate molecular weights (butane, propane) and up to a very large molecules (hexane plus). The relative proportion of these different components can vary in a large range, which results in petroleum fluids showing very different features. For instance, the simplest reservoir fluids are natural gas, while the most complex molecular mixtures are those of black oil and bitumen [17]. The chemical and physical properties of petroleum gases and liquids are stressed, particularly their phase behaviour under subsurface conditions which is shown to be a very important factor in determining migration behavior.

The physical properties of a petroleum fluid are determined by its composition; moreover, many of these hydrocarbons vary significantly as a function of temperature and pressure. Petroleum reservoirs have temperatures that vary from ambient to more than $200^{\circ} \mathrm{C}$ and a pressure that can be as high as $150 \mathrm{MPa}$ [17],[10]. The reservoir conditions depend on the depth of the reservoir and on the geological processes that the reservoir has experienced since it was contained the reservoir fluid [17].

The computational approach for studying physicochemical properties of heavy petroleum factions have been studied by Tovar, et al., [14 cited in 15 ] as their result suggested that the computational approach is a powerful and an efficient tool for predicting the properties of petroleum fractions. Their method required Boiling Temperature curve, and the specific gravity, as the input data information. This method focuses specifically on heavy fraction and selection of a right characterization method for petroleum fraction has an important effect on calculated properties [14 cited in 15]. To sum up, the classification of petroleum and natural gas as naturally occurring mixtures of hydrocarbons occurs by virtue of the fact that they can be separated into their original hydrocarbon constituents that have not been altered by any applied process. The hydrocarbon constituents, separated from petroleum and natural gas, are the hydrocarbon constituents that existed in the reservoir. 


\section{PHYSICAL PROPERTIES OF PETROLEUM CRUDE OIL}

The physical properties of crude oils are the quantitatively measurable characteristics of crude oils. They vary according to the composition of the oil, the relative abundance of the groups of hydrocarbons, and essentially depend on reservoir temperatures and pressures [8]. Physical properties can be observed or measured without changing the composition of matter. Physical properties are used to observe and describe matter. Physical properties that are of interest in the current context include: boiling point, melting point, density, vapor density, flash point, ignition temperature, and dew point [18].

Petroleum exhibits a wide range of physical properties and several relationships can be made between various physical properties [17]. Whereas properties such as viscosity, density, boiling point, and color of petroleum may vary widely. Coupled with the changes brought about to the feedstock constituents by refinery operations, it is not surprising that petroleum characterization is a monumental task [9].

Petroleum refinery processes can be conveniently divided into three different types:

1) Separation: division of the feedstock into various streams (or fractions) depending on the nature of the crude material

2) Conversion: that is, the production of saleable materials from the feedstock by skeletal alteration, or even by alteration of the chemical type of the feedstock constituents

3) Finishing: purification of the various product streams by a variety of processes that remove impurities from the product [9].
Physical properties of the almost limitless variety of crude oils are generally correlated with aspects of chemical composition.

\section{CHEMICAL PROPERTIES}

The chemical properties of crude oils vary in relation to changes in geotemperatures and pressures, variations occurring at all times within the oil pool. Some of the chemical properties are related to the origin, migration, and accumulation of the crude oil [8], coupled with some other elements of katagenesis. Such chemical properties as paraffin wax and perhyrins are complex forms of hydrocarbons which have genetic relationship with living organic-life [1]. Occurrence of isoprenoid hydrocarbons, such as pristanes and phytanes in crude oils, enhances the construction of the genetic environments of deposition of the source rocks. Trace metal substances concentrated in crudes are thought to be derived from sea water as secretions by marine life [8].

\section{PETROLEUM FLUIDS COMPOSITION}

The most important influences on the compositions of petroleum fluids are:

- The depositional environment of their source rocks;

- The temperature at which they were expelled from their source rocks, and

- Biodegradation and phase transformations after they have left their source rocks.

In many cases, the composition of a petroleum sample may allow the depositional environment of its source rock, and its temperature history (before and after expulsion) to be determined. This information assists the search for more petroleum in a region [25]. 
Two determine composition of the petroleum fluids are quantitative and qualitative chemical analysis) have to be known. For a hydrocarbon with a given molecular formula $\mathrm{C}_{\mathrm{x}} \mathrm{H}_{\mathrm{y}}$, the number of possible isomers increases dramatically as the molecule becomes larger. Even for the paraffins in the $\mathrm{C}_{5}-\mathrm{C}_{12}$ range, the number of possible isomers is greater than 600 , around $200-400$ of which have been experimentally observed [1].

\section{v. CHEMICAL COMPOSITION}

Composition refers to the specific mixture of chemical compounds that constitute petroleum. The composition of these materials is related to the nature and mix of the organic material that generated the hydrocarbons [9]. Crude oils are made up of liquid paraffin hydrocarbon compounds ranging from pentane to pentadecane (C5 - C15). All crude oils contain some appreciable amount of the naphthene compounds, ( $10 \%$ by composition). Crude oils also contain a great variety of heteroatomic chemical constituents, comprising of sulphur, oxygen, carbondioxide, nitrogen and trace metals. Nitrogen varies from 0.01 to $2 \%$ as dissolved gas in the crude oil [8].

The chemical composition of petroleum is largely speculative due to the difficulty of a complete identification caused by the enormous number of components [1]. Gases produced from a petroleum reservoir mainly contain alkanes lighter than heptane, with methane and ethane being the predominant components [17]. However, in addition to the hydrocarbons, light non-hydrocarbons compounds including nitrogen, carbon dioxide, and hydrogen sulphide are also present with their proportions are being related to the reservoir originally originated. The composition of petroleum obtained from the well is variable and depends not only on the original composition of the oil in situ but also on the manner of production and the stage reached in the life of the well or reservoir [9].

Crude oils are characterized by some physical and chemical properties, which to a measurable extent, play important role in the understanding of the oils geologic nature and environment of origin, such a physical property as optical activity is dependent on hydrocarbon derivatives from organic cholesterine substances, and are destroyed at high temperatures of about 2000C. They serve as important tools for environmental analysis, reconstruction of temperature history of the oil, and correlation of crude oils of similar geologic ages [8].

Petroleum crude oil, contains larger hydrocarbon molecules with its appearance, composition, and other properties (e.g. heptane plus) vary largely with different petroleum reservoirs. Nevertheless, nearly all naturally occurring petroleum liquids have fairly narrow limits of elemental composition with varying values of percentage weight including: Carbon: (83.087.0\%), Hydrogen: (10.0-14.0\%), Nitrogen:

\section{(0.1-2.0\%), Oxygen: (0.05-1.5\%), Sulfur: (0.05-6.0\%)} [17]. Both the physical nature and chemical composition of petroleum are determined initially by the type of organic matter in the source rock where the petroleum is generated [4].

\section{HYDROCARBON COMPONENTS}

Due to its origin, crude oil is a complex mixture containing thousands of different hydrocarbons [19] that can be separated into a variety of different generic fractions by distillation .And the terminology of these fractions has been bound by utility and often bears little relationship to composition. The major components of petroleum are hydrocarbons, compounds of hydrogen and carbon that display great 
variation in their molecular structure. The simplest hydrocarbons are a large group of chainshaped molecules known as the paraffins [9]. The majority of hydrocarbons found naturally occur in crude oil, where decomposed organic matter provides an abundance of carbon and hydrogen which, when bonded, can catenate to form seemingly limitless chains [18].

The hydrocarbon components of petroleum are commonly accepted to group the different compounds present in crude oils in different families according to their chemical structure (paraffins, naphthenes and aromatics) or polarity (saturates, aromatics, resins and asphaltens) [9]. Olefins (also called alkenes) are so scarce in naturally occurring petroleum that they may be neglected.

Paraffins, called alkanes or known as acyclic alkanes and have the general formula of $\mathrm{C}_{n} \mathrm{H}_{2 \mathrm{n}+2}$, where $\mathrm{n}$ is the number of carbon atoms in a given molecule. Paraffins are divided into two groups of normal and isoparaffins. Both normal and isoparaffins have the same molecular formula $\mathrm{C}_{n} \mathrm{H}_{2 n+2}$. the open formula for n-butane, n- $\mathrm{C}_{4}$, can be shown as $\mathrm{CH}_{3}-\mathrm{CH}_{2}-\mathrm{CH}_{2}-\mathrm{CH}_{3}$, based on the quadrivalency of the carbon atom, and for simplicity, only the carbon-carbon bonds are drawn and most $\mathrm{C}-\mathrm{H}$ bonds are omitted, for more explanation, methane $\left(\mathrm{CH}_{4}\right)$, ethane $\left(\mathrm{CH}_{3} \mathrm{CH}_{3}\right)$, propane $\left(\mathrm{CH}_{3} \mathrm{CH}_{2} \mathrm{CH}_{3}\right)$ are saturated hydrocarbons with straight (normal paraffin) or branched (isoparaffin) chains, but without any ring structure. Paraffins are the largest series of hydrocarbons found in petroleum and beginning with the simplest compound, methane.
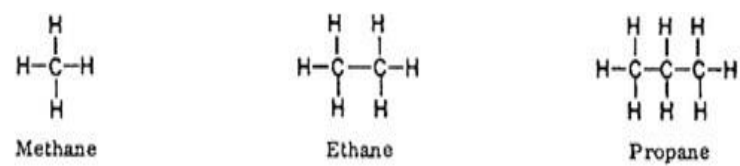

Naphthenes, also recognized as cycloalkanes or alicyclic hydrocarbons, are rings or cyclic saturated hydrocarbons with a general formula of $\left(\mathrm{C}_{n} \mathrm{H}_{2 n} \mathrm{H}_{10}\right)$,

such as cyclopentane $\left(\mathrm{C}_{5} \mathrm{H}_{10}\right)$, methylcyclopentane $\left(\mathrm{C}_{5} \mathrm{H}_{9} \mathrm{CH}_{3}\right)$, dimethylcyclopentane $\left(\mathrm{C}_{5} \mathrm{H}_{8} \mathrm{CH}_{3} \mathrm{CH}_{3}\right)$, and their derivatives such as n-alkylcyclopentanes are normally found in crude oils, and are saturated hydrocarbons containing one or more rings, each of which may have one or more paraffinic side chains. Naphthenes are present in all fractions in which the constituent molecules contain more than five carbon atoms.
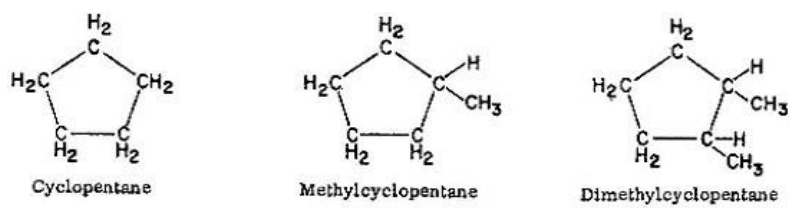

Aromatics, The simplest aromatic hydrocarbon is benzene $\left(\mathrm{C}_{6} \mathrm{H}_{6}\right)$ toluene $\left(\mathrm{C}_{6} \mathrm{H}_{5} \mathrm{CH}_{3}\right)$ containing at least one benzene ring. Aromatic hydrocarbons are an important series of hydrocarbons found in almost every petroleum mixture from any part of the world. Aromatics are cyclic but unsaturated hydrocarbons with alternating double bonds. Many of the aromatic hydrocarbons in petroleum consist of aromatic and naphthenic rings and bear normal and/or branched alkane side chains. Under standard conditions, benzene, toluene, and xylene are in liquid form whereas higher aromatics such as naphthalene occur as solids in isolation, but dissolve to form a liquid solution with simple aromatics.

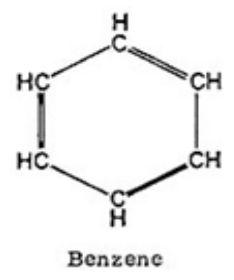

\section{VII.PHYSICAL PROPERTIES OF NARROW DISTILLATION CUTS AND THEIR CHARACTERIZATION}

Characterization of crude oil is an important step in the application of equations of state for pressurevolume-temperature (PVT) predictions and phase behavior calculations. Such calculations are 
needed in reservoir simulation or in the design and operation of refinery distillation columns.

The compositional analysis of petroleum fractions can't provide the necessary information for all of the real components in a petroleum mixture. The compositional information obtained varies with boiling point range [16]. Hydrocarbon components up to $\mathrm{C}_{6}$ and non-hydrocarbon gases including $\left(\mathrm{N}_{2}, \mathrm{CO}_{2}\right.$ and $\mathrm{H}_{2} \mathrm{~S}$ ) can be quantified discretely and the properties of these well-defined components are readily found in literature review. The low boiling range in the $\mathrm{C}_{7+}$ fractions (e.g. up to $\mathrm{C}_{30}$ ) can be fractionated in terms of narrow TBP fractions and their molecular weights and specific gravities can be experimentally determined. For the heavy end of the $\mathrm{C}_{7+}$ fractions, and TBP residue, there was no further analysis of their molar distribution is made and only the molecular weight and specific gravity of the whole residue are experimentally determined. The only available information about the $\mathrm{C}_{7+}$ fraction is its molar composition, specific gravity and molecular weight [16].

The properties involved in the characterization of petroleum hydrocarbon fractions include the molecular weight, $\left(\mathrm{M}_{\mathrm{w}}\right)$, normal boiling point $\left(\mathrm{T}_{\mathrm{b}}\right)$, the specific gravity $(\gamma)$, critical temperature $\left(\mathrm{T}_{\mathrm{c}}\right)$, critical pressure $\left(\mathrm{P}_{\mathrm{c}}\right)$, and the acentric factor $\omega[13]$.

For a pure component, the critical point is the point that terminates the vapour pressure curve, while the critical temperature $\left(\mathrm{T}_{c}\right)$ is the highest temperature at which the substance can exist simultaneously as vapour and liquid. Therefore, at temperatures above $\mathrm{T}_{\mathrm{c}}$ there is no phase transition can occur between vapour and liquid. For pure components, $\mathrm{T}_{\mathrm{c}}$ can be measured in principle and compilations of $T_{c}$ are readily available [13],[14].
Similarly the critical pressure $\left(\mathrm{P}_{\mathrm{c}}\right)$ of a pure component is the highest pressure at which the pure component has a vapour liquid phase transition or it is the highest possible vapour pressure of the component. For the same reasons explained above for the critical temperature, the critical pressure cannot be measured for large hydrocarbon molecules [14].

\section{MATERIALS AND METHODS}

The Messla oil field is the most recent addition to the list of 20 giant fields discovered within the prolific Sirte basin of Libya. The field is located in the southeastern portion of the Sirt Basin, north central Libya, approximately $500 \mathrm{Km}$ Southeast of Benghazi and $40 \mathrm{Km}$ Northwest of the Sarir Oil Field Figures 1and 2 .

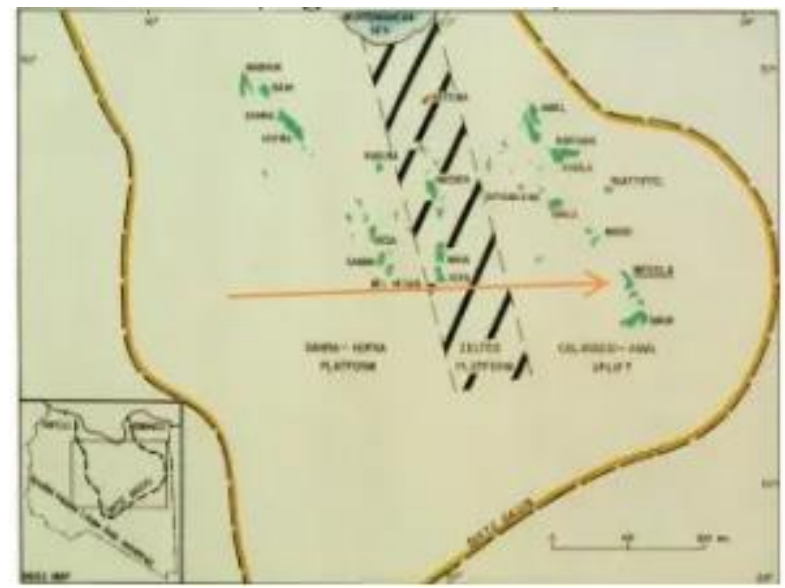

Fig. 1: location of Messla Oil Field (orange arrow)

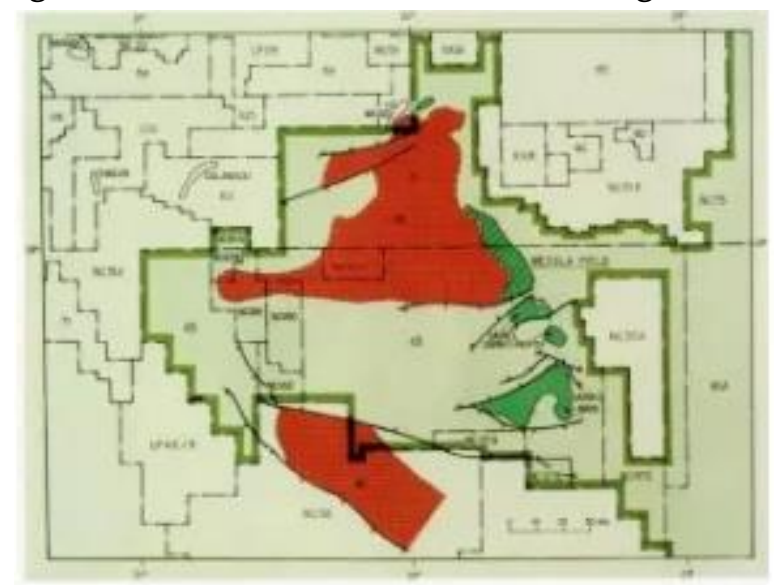


Fig. 2 Index map southeast Sirt basin showing location of Sarir and Messla fields, broad basement highs (BC), and concession boundaries [11].

Properties of physiochemical for instance definite gravity, API gravity, Reid vapour pressure, pour point, initial and final boiling points acidity, salt content sulphur content etc. of petroleum crude oil and petroleum fractions are determined through the data of chemical analysis which carried out on the Messla and Sarir crude oils samples and petroleum products in Tobruk refinery of Libya using different analytical technique as ASTM D86 technique. These properties are used in correlation models to predict the other $f(M W)=1071.28-9.417 \times 10^{4} M W^{0.03522} S G^{3.266} \exp \left(-4.922 \times 10^{-3} M W-\right.$ $4.7685 S G+3.462 \times 10^{-3}$ MWSG) $-k=0$

where

$T_{b}=1.8 k(2)$

$\mathrm{K}$ is Watson characterization factor, $\mathrm{Mw}$ is the molecular weight, and SG is the specific gravity.

B. Normal Boiling Point (Soreide Correlation)

The normal boiling point can be calculated using Equation (3) as following:

$k=1071.28-9.417 \times 10^{4} M W^{0.03522} S G^{3.266} \exp \left(-4.922 \times 10^{-3} M W-\right.$

$\left.4.7685 S G+3.462 \times 10^{-3} M W S G\right)=0$

C. Critical Temperature

The critical temperature can be calculating by applying Equation (4):

$T_{c}=1.8\left[426.7062278+0.95187183 F-6.01889 \times 10^{-4} F^{2}-4.95625 \times\right.$ $10^{-3}(A P I) F+2.160588 \times 10^{-7} F^{3}+2.949718 \times 10^{-6}(A P I) F^{2}+1.817311 \times$ $\left.10^{-8}\left(A P I^{2}\right) F^{2}\right]$

D. Critical Pressure

$P_{c}=14.5038 \times 10^{A}\left[1.6675956+9.412011 \times 10^{-4} \mathrm{~F}-3.047475 \times 10^{-6} F^{2}-\right.$

$2.087611 \times 10^{-5}(A P I) F+1.5184103 \times 10^{-9} F^{3}+1.1047899 \times 10^{-8}(A P I) F^{2}-$ $\left.4.8271599 \times 10^{-8}\left(A P I^{2}\right) F+1.3949619 \times 10^{-10}\left(A P I^{2}\right) F^{2}\right]$

E. Critical Volume (Reidel Correlation)

$V_{c}=\frac{10.732 T_{c}}{M W P_{c}[3.72+0.26(5.811+4.919 \omega-7)]}$ 
where

$A P I=\frac{141.5}{S G}-131.5$

$F=T_{b}-459.67(7)$

F. Acentric Factor (Korsten's Correlation)

$\omega=0.5899 \log \left[\frac{P_{c}}{14.696}\right] /\left[\left(\frac{T_{c}}{T_{b}}\right)^{1.3}-1\right]-1$

\section{Twu Correlations}

Twu (1984) [21] used the critical properties from back-calculated to obtain his correlations for undefined petroleum fractions as following:

A. Critical Temperature

$T_{c}=T_{c}^{0}\left[\left(1+2 f_{r}\right) /\left(1-2 f_{r}\right)\right]^{2}$

where

$T_{\circ}^{0}=k /\left(0.533272+0.34383 \times 10^{-3} k+2.52617 \times 10^{-7} k^{2}-1.65848 \times\right.$

$\left.10^{-10} k^{3}+4.60773 \times 10^{24} k^{-13}\right)$

$f_{r}=\Delta S G_{T}\left[-0.27016 / k^{0.5}+\left(0.0398285-\frac{0.706691}{k^{0.5}}\right) \Delta S G_{T}\right]$

$\Delta S G_{T}=\exp \left[5\left(S G^{0}-S G\right)\right]-1$

$\Delta S G_{T}=0.843593-0.128624 \alpha^{12}$

$k=T_{b} / 1.8$

$\alpha=1-\left(k / T_{c}^{0}\right)$

B. Critical Volume

$V_{c}=V_{c}^{0}\left[\left(1+2 f_{V}\right) /\left(1-2 f_{V}\right)\right]^{2}$

where

$V_{c}^{0}=\left(0.34602+0.30171 \alpha+0.93307 \alpha^{3}+5655.414 \alpha^{14}\right)^{8}$

$f_{V}=\Delta S G_{V}\left[0.347776 / k^{0.5}+\left(-0.182421+\frac{2.248896}{k^{0.5}}\right) \Delta S G_{V}\right]$

$\Delta S G_{V}=\exp \left[4\left(S G^{0.2}-S G^{2}\right)\right]-1(19)$

C. Critical Pressure

$P_{c}=P_{c}^{0}\left(T_{c} / T_{c}^{0}\right)\left(V_{c}^{0} / V_{c}\right)\left[\left(1+2 f_{p}\right) /\left(1-2 f_{p}\right)\right]^{2}(20)$

where

$P_{c}^{0}=\left(1.00661+0.31412 \alpha^{0.5}+9.16106 \alpha+9.5041 \alpha^{2}+27.35886 \alpha^{4}\right)^{2}$ 


$$
\begin{aligned}
& f_{P}=\Delta S G_{P}\left[\left(2.53262-\frac{34.4321}{k^{0.5}}-\frac{2.30193 k}{1000}\right)+\left(-11.4277+\frac{187.934}{k^{0.5}}+\frac{4.11963 k}{1000}\right) \Delta S G_{P}\right] \\
& \Delta S G_{p}=\exp \left[0.5\left(S G^{0}-S G\right)\right]-1
\end{aligned}
$$

D. Molecular Weight

$$
\begin{aligned}
& M w=\exp \left\{\beta\left[\left(1+2 f_{M}\right) /\left(1-2 f_{M}\right)\right]^{2}\right\}(24) \\
& f(\beta)=\exp \left(5.12640+2.71579 \beta-0.286590 \beta^{2}-\frac{39.8544}{\beta}-\frac{0.122488}{\beta^{2}}\right)- \\
& 13.7512 \beta+19.6197 \beta^{2}-k=0 \\
& f_{M}=\Delta S G_{M}\left[x+\left(-0.0175691+0.143979 / k^{0.5}\right) \Delta S G_{M}\right] \\
& x=\left|0.012342-0.244541 / k^{0.5}\right| \\
& \Delta S G_{M}=\exp \left[5\left(S G^{0}-S G\right)\right]-1
\end{aligned}
$$

E. Critical Compressibility Factor

$Z_{c}=\frac{P_{c} V_{c}}{R T_{c}}=\frac{P_{c} V_{c}}{83.14 T_{c}}$

F. Acentric Factor (Edmister's Correlation)

$\omega=\frac{3}{7} \log \left[\frac{P_{c}}{1.01325}\right] /\left[\left(\frac{T_{c}}{k}\right)-1\right]-1$

\section{Riazi-Daubert Correlations}

Riazi and Daubert (1987) [15] developed a set of equations to evaluate properties of undefined petroleum fractions. Given specific gravity $(\mathrm{SG})$ and boiling point $\left(\mathrm{T}_{\mathrm{b}}\right)$ or molecular weight $(\mathrm{Mw})$ of the petroleum fraction, physical properties are estimated as follows:

A. Molecular Weight $(\mathrm{Mw})$

If specific gravity (SG) and boiling point $(\mathrm{Tb})$ of the petroleum fraction are given, molecular weight $(\mathrm{Mw})$ is estimated as follows:

$M w=42.965 k^{1.6007} S G^{4.98308} \exp \left(2.097 \times 10^{-4} k-7.78712 S G+2.08476 \times\right.$

$\left.10^{-3} k S G\right)$

Where

$k=\frac{T_{b}}{1.8}$

B. Normal Boiling Point (NBP)

In case boiling point $\left(\mathrm{T}_{\mathrm{b}}\right)$ of the petroleum fraction is not known and molecular weight $(\mathrm{Mw})$ is given instead, the above equation is rearranged and solved iteratively for $\mathrm{k}$. The objective function for the nonlinear solver is given by: 
$f(k)=42.965 k^{1.26007} S G^{4.98308} \exp \left(2.097 \times 10^{-4} k-7.78712 S G+2.08476 \times\right.$

$\left.10^{-3} k S G\right)-M W=0$

C. Critical Temperature $\left(T_{c}\right)$

$T_{c}=17.14194 k^{0.8107} S G^{0.33691} \exp \left(-9.314 \times 10^{-4} k-0.544442 S G+6.4791 \times\right.$

$10^{-4} k S G$ )

D. Critical Pressure $\left(P_{c}\right)$

$P_{c}=46.35124404 \times 10^{5} k^{-0.4844} S G^{4.0846} \exp \left(-8.505 \times 10^{-3} k-4.8014 S G+\right.$

$5.749 \times 10^{-3} k S G$ )

E. Critical Volume $\left(V_{c}\right)$

$V_{c}=9.689574 \times 10^{-4} k^{-0.7506} S G^{-1.2028} \exp \left(-2.64222 \times 10^{-3} k-0.26404 S G+\right.$

$1.971 \times 10^{-3} \mathrm{kSG}$ )

F. Critical Compressibility $\left(Z_{c}\right)$

Critical compressibility may be conveniently calculated by the real gas equation-of-state at the critical point as follows:

$Z_{c}=\frac{P_{c} V_{c} M W}{R T_{c}}=\frac{P_{c} V_{c} M W}{10.732 T_{c}}$

G. Watson Factor $(K)$

The Watson factor is calculated from its definition as follows:

$K=\frac{T_{\delta}^{1 / B}}{S G}$

H. Acentric Factor (Edmister's Correlation) ( $\omega)$

$\omega=\frac{3}{7} \log \left[\frac{P_{c}}{14.696}\right] /\left[\left(\frac{T_{c}}{T_{b}}\right)-1\right]-1$

J. Acentric Factor (Korsten's Correlation)

$\omega=0.5899 \log \left[\frac{P_{c}}{14.696}\right] /\left[\left(\frac{T_{c}}{T_{b}}\right)^{1.3}-1\right]-1$

Where $\mathrm{T}_{\mathrm{b}}$ and $\mathrm{T}_{\mathrm{c}}$ are in ${ }^{\circ} \mathrm{R}, \mathrm{P}_{\mathrm{c}}$ is in psia, and $\mathrm{V}_{\mathrm{c}}$ is in $\mathrm{ft}^{3} / \mathrm{lb}$.

\section{Kesler-Lee Correlations}

Kesler and Lee (1976) [12] developed a set of equations to evaluate properties of undefined petroleum fractions. Given specific gravity $(\mathrm{SG})$ and boiling point $\left(\mathrm{T}_{\mathrm{b}}\right)$ or molecular weight $(\mathrm{Mw})$ of the petroleum fraction, physical properties are estimated as follows:

A. Molecular Weight $(\mathrm{Mw})$ 
$M w=-12,272.6+9,486.4 S G+(8.3741-5.991 S G) k+(1-0.77084 S G-$

$\left.0.02058 S G^{2}\right)\left\{0.7465-\frac{222.466}{k}\right\} \frac{10^{7}}{k}+\left(1-0.80882 S G+0.02226 S G^{2}\right)\{0.3228-$

$\left.\frac{17.335}{k}\right\} \frac{10^{12}}{k^{8}}$

Where

$K=\frac{T_{b}}{1.8}(42)$

B. Normal Boiling Point

In case boiling point $\left(\mathrm{T}_{\mathrm{b}}\right)$ is not known and molecular weight $(\mathrm{Mw})$ is given instead, the above equation is rearranged and solved iteratively for $\mathrm{k}$. The objective function for the nonlinear solver is given by:

$f(k)=-12,272.6+9,486.4 S G+(8.3741-5.991 S G) k+(1-0.77084 S G-$

$\left.0.02058 S G^{2}\right)\left\{0.7465-\frac{222.466}{k}\right\} \frac{10^{7}}{k}+\left(1-0.80882 S G+0.02226 S G^{2}\right)\{0.3228-$

$\left.\frac{17.335}{k}\right\} \frac{10^{12}}{k^{3}}-M W=0$

C. Critical Temperature $\left(T_{\bullet}\right)$

$T_{c}=1.8\left[\begin{array}{c}189.8+450.6 S G+(0.4244+0.1174 S G) k+ \\ \frac{(0.1441-1.0069 S G) 10^{5}}{k}\end{array}\right]$

D. Critical Pressure $\left(P_{c}\right)$

$P_{c}=14.5038 \exp \left\{5.689-\frac{0.0566}{S G}-\left(0.43639+\frac{4.1216}{S G}+\frac{0.21343}{S G^{2}}\right) \frac{k}{10^{\mathrm{g}}}+\right.$

$\left.\left(0.47579+\frac{1.182}{S G}+\frac{0.15302}{S G^{2}}\right) \frac{k^{2}}{10^{6}}-\left(2.4505+\frac{9.9099}{S G^{2}}\right) \frac{k^{\mathrm{g}}}{10^{10}}\right\}$

D. Acentric Factor $(\omega)$

$\omega=\left\{\begin{array}{lc}-7.904+0.1352 k-0.007465 k^{2}+8.35 T_{b r}+\frac{(1.408-0.01063 k)}{T_{b r}} & T_{b r>0.8} \\ \frac{-\ln \left(\frac{P_{c}}{14.696}\right)-5.92714+\frac{6.09648}{T_{b r}}+1.28862 \ln \left(T_{b r}\right)-0.169347 T_{b r}^{6}}{15.2518-\frac{15.6875}{T_{b r}}-13.4721 \ln \left(T_{b r}\right)+0.43577 T_{b r}^{6}} & T_{b r \leq 0.8}\end{array}\right.$

where

$T_{b r}=\frac{T_{b}}{T_{c}}$

$K=\frac{T_{b}^{k k}}{S G}$

E. Critical Compressibility Factor $\left(Z_{c}\right)$

$Z_{c}=0.2905-0.0850 \omega$

F. Critical Volume (General Definition) 
$V_{c}=\frac{R T_{c} z_{c}}{M W P_{c}}$

Where $\mathrm{T}_{\mathrm{b}}$ and $\mathrm{T}_{\mathrm{c}}$ are in ${ }^{\circ} \mathrm{R}, \mathrm{P}_{\mathrm{c}}$ is in psia, and $\mathrm{V}_{\mathrm{c}}$ is in $\mathrm{ft}^{3} / \mathrm{lb}$.

\section{THERMOPHYSICAL PROPERTIES OF PETROLEUM FRACTIONS AND CRUDE OILS}

1) API Gravity $\left({ }^{\circ} \boldsymbol{A P I}\right)$ : can be calculating by knowing oil specific gravity.

${ }^{\circ} A P I=\frac{141.5}{S G @ 60^{\circ} \mathrm{F}}-131.5$

2) Correlation Index (CI): it can be calculated at TBP (50) as following:

C. $I .=\frac{48640}{T_{B}}+473.7 S G-456.8$

3) Watson characterization factor $(\mathrm{K})[22],[2]$ : by calculating volume average boiling point (VABP), $\mathrm{K}$ value can be estimated as following:

$\mathrm{VABP}=\frac{T_{10}+T_{80}+T_{50}+T_{70}+T_{90}}{5}$

Then, the mean average boiling point (MeABP) can be calculated after the calculation of $\Delta$ and SL as following:

$\mathrm{SL}=\frac{T_{90}-T_{10}}{90-10}$

$\ln \Delta=-0.94402-0.00865(V A B P-32)^{0.6667}+2.99791 S L^{0.333}$

$\mathrm{MeABP}=\mathrm{VABP}-\Delta(56)$

According to this value the crude oil can be classified as napthene base.

4) Pour Point: it is an index for paraffins an aromatic compounds.

$\mathrm{PP}=753+136\left[1-\exp \left(-0.15_{v_{100}}\right)\right]-572 S G+0.0512_{v_{100}}+0.139 \mathrm{MeABP}$

5) Cloud Point: can be estimated by knowing pour point from this equation:

$\log C P=-7.41+5.49 \log M e A B P-0.712 M e A B P^{0.315}-0.133 S G$

$\mathrm{PP}=0.9895 \mathrm{CP}+1.4(59)$

6) Diesel Index: it is estimated by this relation:

Diesel Index $=\frac{{ }^{\circ A P I} \text { Aniline point }\left({ }^{\circ} \mathrm{F}\right)}{100}$

\section{RESULTS AND DISCUSSION}

Tobruk refinery is designed to process different petroleum crude oils including Messla and Sarir mix crude oils. The more important properties of this mix are listed in Table 1, while Table 2 shows the distillation products of crude oil. The true boiling point is varying for different fractions between initial boiling point (IBP) and the final boiling point (FBP). The true boiling point (TBP) of petroleum fractions according ASTM D86 method is reported in Table 3. 
Table 1 : Properties of Messla and Sarir mix [3]

\begin{tabular}{|c|c|c|}
\hline No. & Property & Value \\
\hline 1 & API gravity @ $60{ }^{\circ} \mathrm{F}$ & 38.9 \\
\hline 2 & Distillation test: IP 123/D86 & 52.5 \\
\hline 3 & IBP, ${ }^{\circ} \mathrm{C} 670 \mathrm{mms}$ & 365.0 \\
\hline 4 & Final Boiling Point & 0.16 \\
\hline 5 & Sulfur content, wt\% & 10.70 \\
\hline 6 & $\begin{array}{c}\text { Kinematics viscosity @ 100 } \\
{ }^{\circ} \mathrm{F}, \mathrm{cst}\end{array}$ & 3.2 \\
\hline 7 & $\begin{array}{c}\text { Salt content as NaCl, Ib/1000 } \\
\text { bbl }\end{array}$ & 0.080 \\
\hline 8 & Acidity, mg KOH/g & $<1.0$ \\
\hline 9 & Hydrogen sulphide, ppm & $6(0.85)$ \\
\hline 10 & $\begin{array}{c}\text { Reid vapour pressure, } \mathrm{kPa} \\
\text { (psi) }\end{array}$ & 24 \\
\hline 11 & Pour point, ${ }^{\circ} \mathrm{C}$ & {$[3]$} \\
\hline
\end{tabular}

Table 2 : Distillation products of crude oil [3]

\begin{tabular}{|c|c|c|c|c|c|}
\hline Products & $\begin{array}{c}\text { Light } \\
\text { naphth } \\
\mathrm{a}\end{array}$ & $\begin{array}{c}\text { Heavy } \\
\text { naphth } \\
\mathrm{a}\end{array}$ & $\begin{array}{c}\text { Kerose } \\
\text { ne }\end{array}$ & $\begin{array}{c}\text { Dies } \\
\mathrm{el}\end{array}$ & $\begin{array}{c}\text { Residu } \\
\mathrm{e}\end{array}$ \\
\hline $\begin{array}{c}\text { True } \\
\text { boiling } \\
\text { point } \\
\text { (TBP), } \\
{ }^{\circ} \mathrm{C}\end{array}$ & 95 & 160 & 255 & 325 & 402 \\
\hline $\begin{array}{c}\text { Distillatio } \\
\text { n percent }\end{array}$ & 15.4 & 31.5 & 22.9 & 18.8 & 11.02 \\
\hline
\end{tabular}

Table 3 : True boiling points of petroleum fractions [3]

\begin{tabular}{|c|c|c|c|c|}
\hline $\begin{array}{c}\text { True } \\
\text { boiling } \\
\text { point } \\
\text { (TBP), }{ }^{\circ} \mathrm{C}\end{array}$ & $\begin{array}{c}\text { Light } \\
\text { naphtha }\end{array}$ & $\begin{array}{c}\text { Heavy } \\
\text { naphtha }\end{array}$ & Kerosene & Diesel \\
\hline IBP & 32 & 79 & 112 & 200 \\
\hline $5 \%$ vol. & 53 & 137 & 166 & 211 \\
\hline $10 \%$ vol. & 63 & 138 & 169 & 221 \\
\hline $20 \%$ vol. & 68 & 141 & 171 & 232 \\
\hline $30 \%$ vol. & 75 & 142 & 175 & 242 \\
\hline $40 \%$ vol. & 81 & 144 & 176 & 252 \\
\hline $50 \%$ vol. & 87 & 146 & 179 & 264 \\
\hline
\end{tabular}

\begin{tabular}{|c|c|c|c|c|}
\hline $60 \%$ vol. & 95 & 148 & 180 & 278 \\
\hline $70 \%$ vol. & 102 & 149 & 183 & 291 \\
\hline $80 \%$ vol. & 108 & 152 & 185 & 307 \\
\hline $90 \%$ vol. & 116 & 155 & 189 & 326 \\
\hline $95 \%$ vol. & 121 & 158 & 192 & 340 \\
\hline FBP & 132 & 172 & 202 & 347 \\
\hline
\end{tabular}

\section{CALCULATIONS OF PHYSICAL PROPERTIES OF PETROLEUM FRACTIONS}

The calculations of physical properties of petroleum fractions are reported in Table 4 by correlations models using the equations (1) through (50). The petroleum fractions are light naphtha, heavy naphtha, kerosene and diesel. These properties include critical temperature $\left(\mathrm{T}_{\mathrm{c}}\right)$, critical pressure $\left(\mathrm{P}_{\mathrm{c}}\right)$, critical volume $\left(\mathrm{V}_{c}\right)$, acentric factor $(\omega)$, Watson factor $(\mathrm{K})$, compressibility factor $\left(\mathrm{Z}_{\mathrm{c}}\right)$ and molecular weight $(\mathrm{Mw})$.

The different parameters of calculations for the petroleum fractions (Light naphtha, Heavy naphtha, Kerosene, Diesel) were compared with other published data e.g. Cavett, Twu, Riazi-Daubert and Kesler-Lee. The obtained results show more or less similarity between the applied correlations for the calculated physical properties of different petroleum fractions (Table 4). However, Figures 1 through 7 depict these similarities.

\section{THERMOPHYSICAL PROPERTIES OF PETROLEUM FRACTIONS AND CRUDE OILS}

The calculation of some thermophysical properties of petroleum fractions and crude oils by using the equations (51) (API Gravity, Correlation Index, Watson characterization factor, Pour Point, Cloud Point, Diesel Index) through (60) are reported in Table 5. The obtained results within the characterization features of required products. 
Table 4 : Calculated physical properties

\begin{tabular}{|c|c|c|c|c|}
\hline Correlations & Light naphtha & Heavy naphtha & Kerosene & Diesel \\
\hline \multicolumn{5}{|c|}{ Critical temperature $\left(\mathrm{T}_{c}\right)$} \\
\hline Cavett & 511.2 & 540.0 & 710.2 & 780.0 \\
\hline Twu & 520.9 & 556.3 & 705.6 & 783.5 \\
\hline Riazi-Daubert & 504.5 & 580.8 & 704.9 & 790.2 \\
\hline Kesler-Lee & 502.2 & 580.4 & 701.2 & 786.3 \\
\hline \multicolumn{5}{|c|}{ Critical pressure $\left(\mathrm{P}_{c}\right)$} \\
\hline Cavett & 32.0 & 25.9 & 17.2 & 12.8 \\
\hline Twu & 35.2 & 24.9 & 16.9 & 13.0 \\
\hline Riazi-Daubert & 34.1 & 26.2 & 17.5 & 13.4 \\
\hline Kesler-Lee & 33.4 & 26.8 & 17.9 & 12.7 \\
\hline \multicolumn{5}{|c|}{ Critical volume $\left(\mathrm{V}_{c}\right)$} \\
\hline Cavett & 380.2 & 505.1 & 830.2 & 1203.0 \\
\hline Twu & 375.5 & 498.2 & 835.6 & 1199.6 \\
\hline Riazi-Daubert & 390.5 & 500.1 & 822.0 & 1220.0 \\
\hline Kesler-Lee & 370.2 & 488.5 & 850.4 & 1175.7 \\
\hline \multicolumn{5}{|c|}{ Acentric factor $(\omega)$} \\
\hline Cavett & 0.3751 & 0.4233 & 0.4351 & 0.5899 \\
\hline Twu & 0.4222 & 0.4031 & 0.4424 & 0.5911 \\
\hline Riazi-Daubert & 0.3850 & 0.4199 & 0.4569 & 0.6036 \\
\hline Kesler-Lee & 0.4211 & 0.4422 & 0.4980 & 0.5966 \\
\hline \multicolumn{5}{|c|}{ Watson factor (K) } \\
\hline Cavett & 11.8021 & 11.8212 & 11.7812 & 11.8900 \\
\hline Twu & 11.5914 & 11.8421 & 11.8811 & 11.9011 \\
\hline Riazi-Daubert & 11.8125 & 11.8311 & 11.7588 & 11.8920 \\
\hline Kesler-Lee & 11.7721 & 11.8400 & 11.7844 & 11.9020 \\
\hline \multicolumn{5}{|c|}{ Compressibility factor $\left(\mathrm{Z}_{c}\right)$} \\
\hline Cavett & 0.2450 & 0.2477 & 0.2378 & 0.2455 \\
\hline Twu & 0.2488 & 0.2461 & 0.2422 & 0.2399 \\
\hline Riazi-Daubert & 0.2499 & 0.2457 & 0.2366 & 0.2324 \\
\hline Kesler-Lee & 0.2410 & 0.2441 & 0.2315 & 0.2311 \\
\hline \multicolumn{5}{|c|}{ Molecular weight $(\mathrm{Mw})$} \\
\hline Cavett & 146 & 152 & 165 & 173 \\
\hline Twu & 144 & 154 & 172 & 171 \\
\hline Riazi-Daubert & 147 & 153 & 162 & 170 \\
\hline Kesler-Lee & 145 & 155 & 171 & 173 \\
\hline
\end{tabular}


Table 5 : Thermophysical properties of petroleum fractions and crude oils

\begin{tabular}{|c|c|c|c|c|c|}
\hline 'API Gravity & $\begin{array}{c}\text { Correlation Index } \\
(\mathrm{CI})\end{array}$ & $\begin{array}{c}\text { Watson characterization } \\
\text { factor }(\mathrm{K})\end{array}$ & Pour Point & Cloud point & Diesel index \\
\hline 38.5 & 6.03 & 11.45 & 22.84 & 21.66 & 51 \\
\hline
\end{tabular}

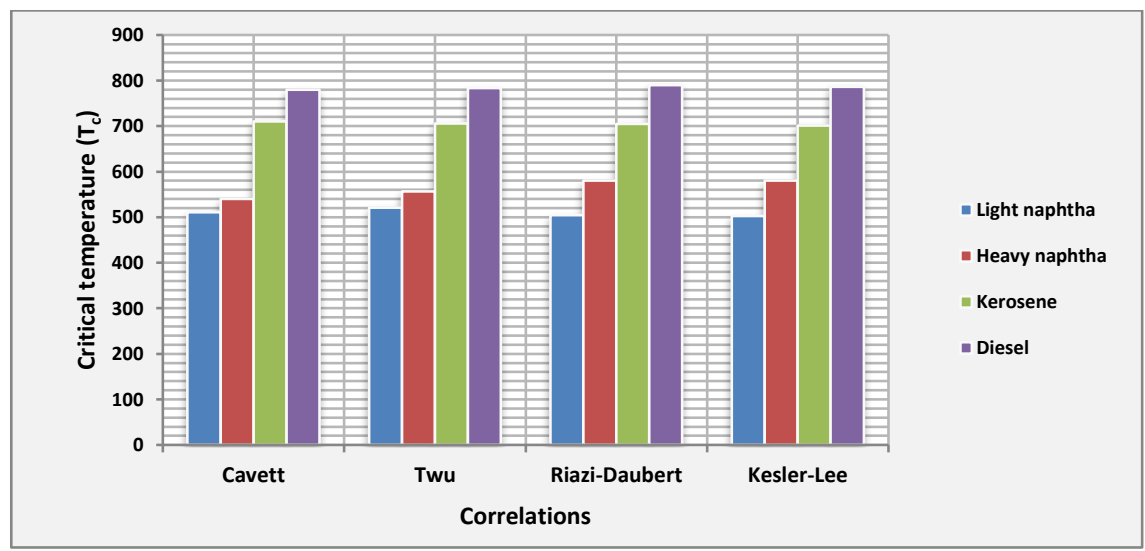

Fig. 3: Critical temperature of petroleum fractions

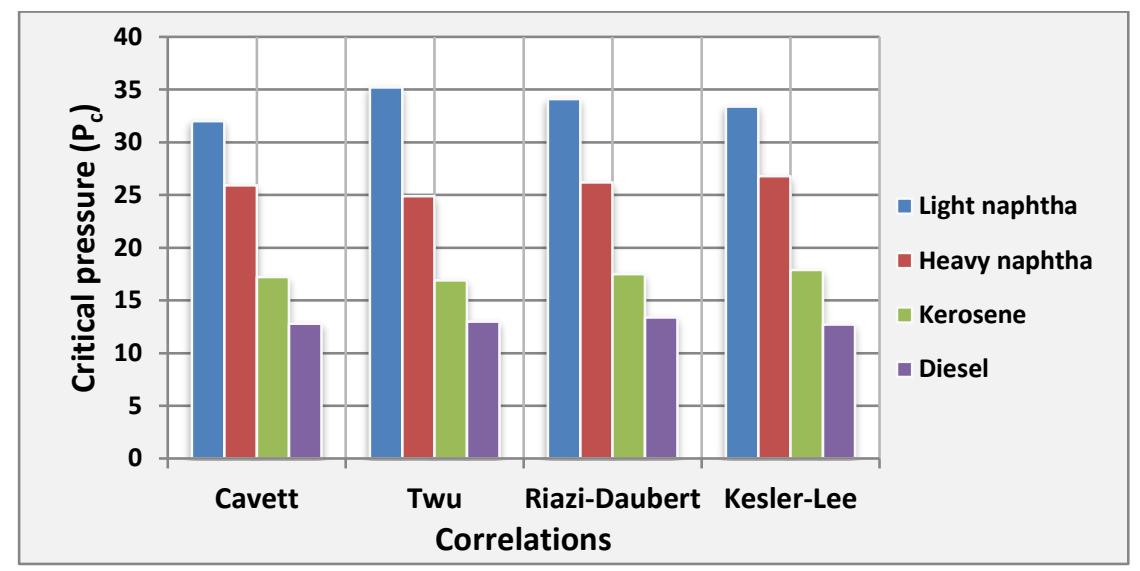

Fig. 4: Critical pressure of petroleum fractions

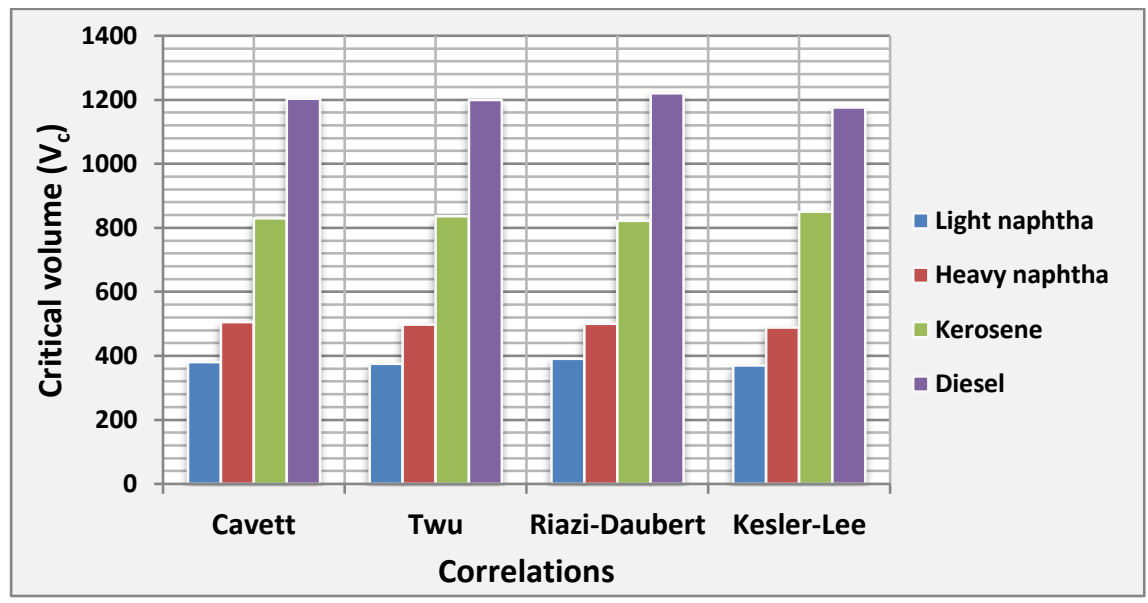


Fig. 5: Critical volume of petroleum fractions

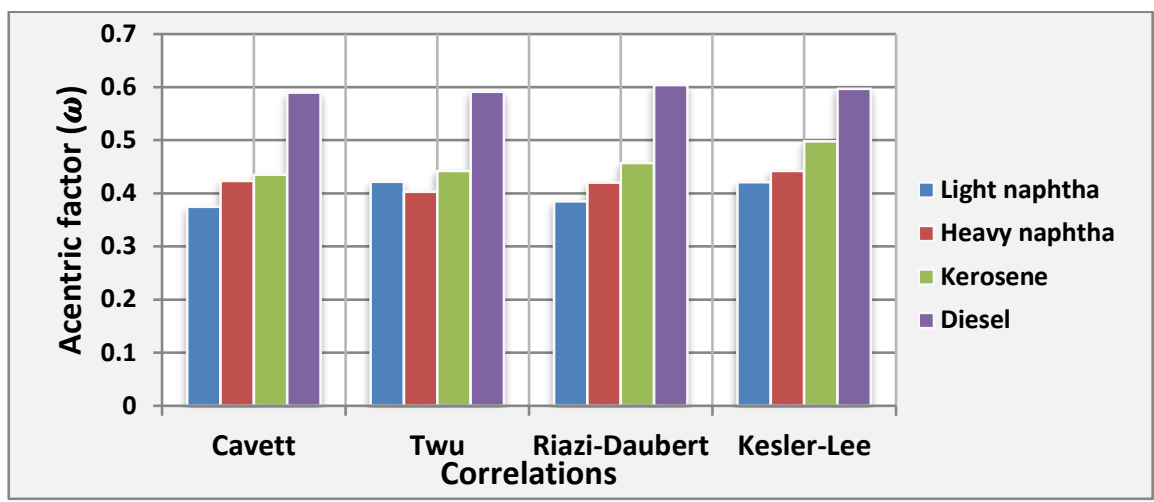

Fig. 6: Acentric factor of petroleum fractions

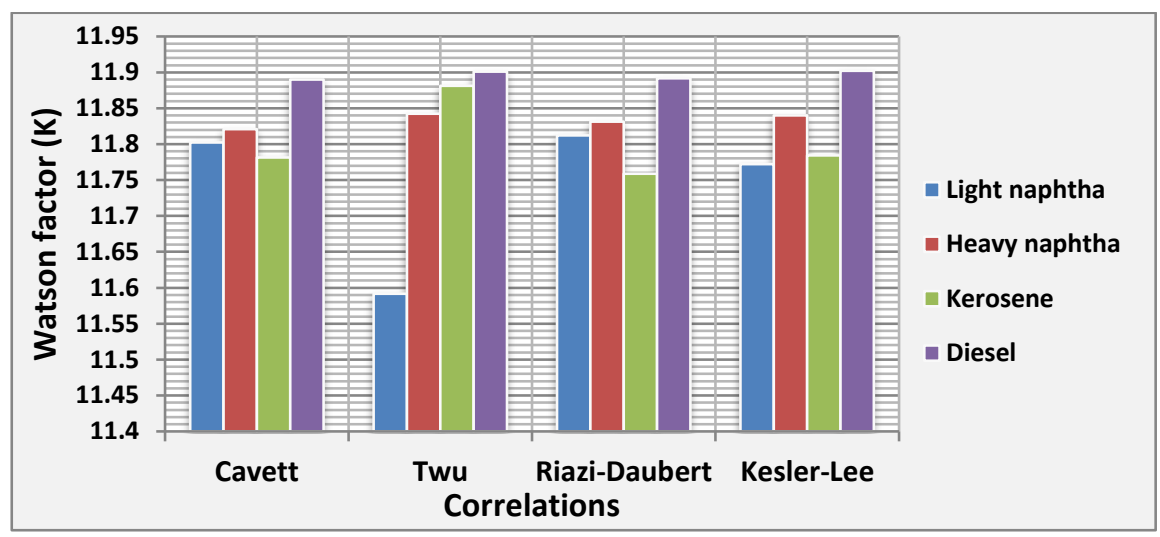

Fig. 7: Watson factor of petroleum fractions

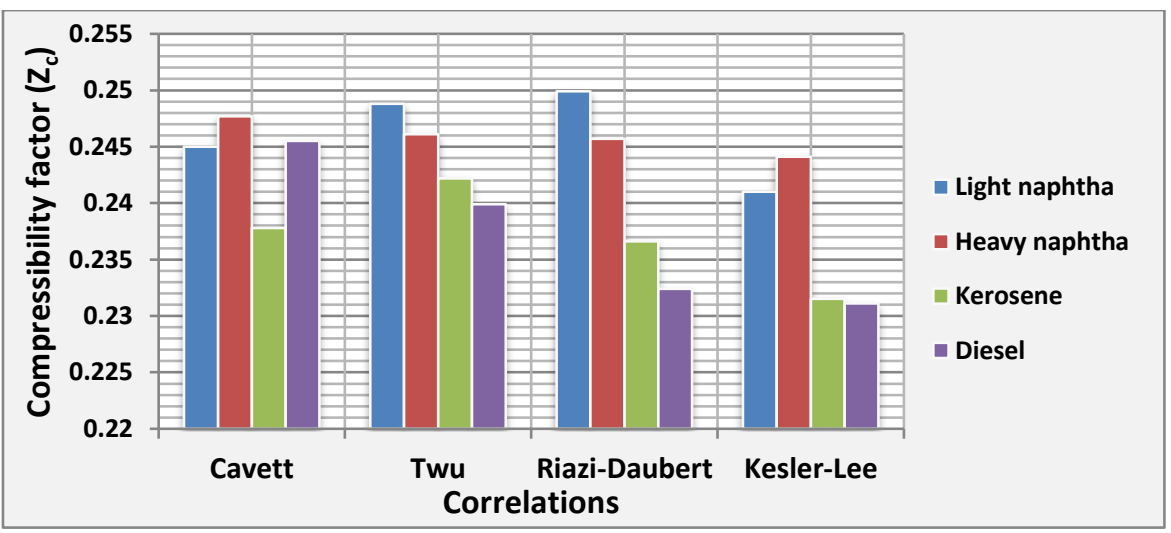

Fig. 8: Compressibility factor of petroleum fractions 


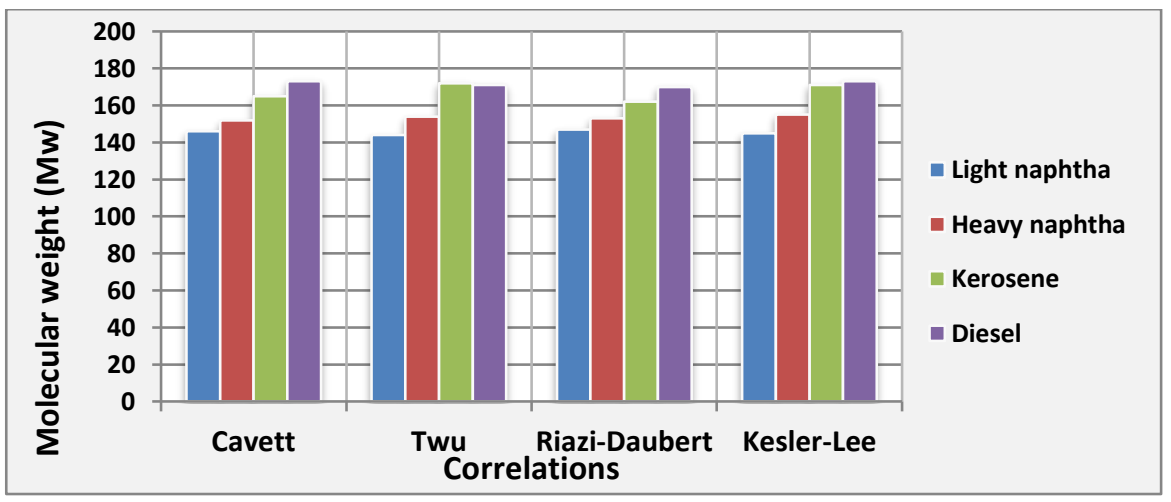

Fig. 9: Molecular weight of petroleum fractions

\section{CONCLUSION}

The most common correlations for characterizing undefined petroleum fractions, that were presented in literature and have gotten a wide acceptance in the oil industry, are revised. The only required input parameters are specific gravity and normal boiling point or molecular weight. Calculated properties include: normal boiling point (if molecular weight is supplied), molecular weight (if normal boiling point is supplied), critical properties and acentric factor.

Empirical correlations were extensively used in calculating PVT properties. Estimation of the missing quantities: ${ }^{\gamma}$, Mw and Tb. The specific gravity ${ }^{\gamma}$, the molecular weight $\mathrm{M}$, and the normal boiling point $\mathrm{Tb}$ form the minimum set required for the characterization of a narrow petroleum fraction. Sometimes, experimental values of two of them (typically $\mathrm{Tb}$ and ${ }^{\gamma}$, or $\mathrm{M}$ and ${ }^{\gamma}$ ), are unknown and have to be estimated. TBP data for oils from a similar region can be used as a good reference.

In this study, the known physical properties including $\gamma$ and $\mathrm{Tb}$ are generally used in correlation models to estimate the properties of petroleum fractions of crude oils under considerations. The calculations reveal that there is no much difference between correlation models and the obtained results seem to be very close with similar published data. These correlations can be applicable to predict the physical properties of petroleum fractions of different crude oils.

\section{REFERENCES}

[1]. Altgelt, K.H., and Boduszynski, M.M. (1994) Composition and analysis of heavy petroleum fractions, New York, Marcel Dekker.

[2]. American Petroleum Institute, API (1997) Technical Data Book- Petroleum Refining.

[3]. AGOCO (2019) Arabian Gulf Oil Company.

[4]. Barker, C. (1985) Origin, Composition and Properties of Petroleum. Chapter 2, Developments in Petroleum Science, Vol.17, part A, pp. 11-45.

[5]. Belghit C., Yasmina L. and Albahric T. (2018) New empirical correlation for estimation of vaporization enthalpy of algerian saharan blend petroleum fractions. PETROLEUM SCIENCE AND TECHNOLOGY, VOL. 36, NO. 15, PP. 1181-1186.

[6]. Cavett, R.H., (1962) "Physical Data for Distillation Calculations-Vapor-Liquid Equilibrium," Proc. 27th Meeting, API, San Francisco, pp. 351-366.

[7]. Chang, A.-F., Pashikanti, K. \& Liu, Y. A., 2013. Characterization, Physical and Thermodynamic Properties of Oil Fraction. In: Refinery Engineering: Integrated Process Modelling and Optimization. Germany: Wiley-VCH Verlag GmbH \& Co. KGaA, pp. 1-55.

[8]. Chinenyeze M. and Ugwu E. (2017) Physical and Chemical Properties of Crude Oils and Their Geologic Significances. International Journal of 
Science and Research (IJSR), Vol. 6 Issue 6, pp. 1514-1521

[9]. El-Naggar A, El-Fadly A., Mustafa Y., Ebiad M. and EmanI. (2014) Petroleum in View of its Classification, Assay and Analysis. International Science Congress Association. Available on https://www.researchgate.net/publication/283727 681_Petroleum

_in_View_of_its_Classification_Assay_and_Analy sis . Accessed on 17/8/2020

[10]. El-Hadi Djamel (2016) Novel correlations for the prediction of the chemical composition of petroleum fluids fractions at base experimental data. Arabian Journal of Geosciences volume 9, Article number: 339 (2016)

[11]. Haweel H., Hlal O. , Alajail A. (2016) Petrographic Analysis of the Sarir Sandstone in Messla Oil Field, Southeast Sirte Basin, North Central Libya. The 1st International Conference on Chemical, Petroleum, and Gas Engineering (ICCPGE 2016) 20th - 22th December 2016, Alkhoms-Libya

[12]. Kesler, M. G., and Lee. B. I., (1976) "Improved Prediction of Enthalpy of Fractions," Hydrocarbon Processing, pp. 153-158.

[13]. Nikitin E.D. (1994) Critical constants of $n$-alkanes with from 17 to 24 carbon atoms, "Journal of Chemical Thermodynamics», 26, 177-182.

[14]. Poling B.E. (2000) the properties of gases and liquids, New York-London, McGraw-Hill.

[15]. Rawaz A., Karim A., Jamel S., Hamma-Saeed V., and Hussein B. (2016) Physical properties as indication for chemical composition of petroleum fraction of Hassira and Khurmala crude oil. International Journal of Engineering and Applied Sciences (IJEAS) ISSN: 2394-3661, 070-Vol.3, Issue-9, pp. 21-26.

[16]. Riazi, M. R. and Daubert, T. E., (1987) "Characterizing Parameters for Petroleum Fractions," Ind. Eng. Chem. Res., Vol. 26, pp. 755759.

[17]. Speight, J.G. (2001) Handbook of petroleum analysis, New York, John Wiley.
[18]. Sparkman O., Penton Z. and Kitson F. (2011) Gas Chomatography and Mass Spectrometry: A Practical Guide. Book 2nd Edition, 2011, Academic Press, No. of pp. 632.

[19]. Speight J. G. The chemistry and technology of petroleum; Marcel Dekker, Inc.:New York, 2006.

[20]. Tovar, L. P. et al., 2010. Computational Approach for Studying Physicochemical Properties of Heavy Petroleum Fractions. In: S. Pierucci \& G. Buzzi Ferraris, eds. Computer Aided Chemical Engineering. Pierucci, S.;Buzzi Ferraris, G. ed. s.1.:20th European Symposium on Computer Aided Process Engnieering-ESCAPE20, pp. 11342.

[21]. Twu, C.H., (1984) An Internally Consistent Correlation for Predicting the Critical Properties and Molecular Weights of Petroleum and CoalTar Liquids: Fluid Phase Equilibria 16, 137.

[22]. Whitson, C.H., (1983) Characterizing hydrocarbon plus fractions: SPEJ 23: 683-694.

[23]. Whitson C.H. (1983) Characterizing hydrocarbon plus fractions, «Society of Petroleum Engineers Journal», August, 683-694.

[24]. Whitson C.H., and Brule M.R. (2000) Phase Behaviour, Richardson (TX), Society of Petroleum Engineers.

[25]. W. A. England \& A. S. Mackenzie (1989) Some aspects of the organic geochemistry of petroleum fluids. Geologische Rundschau volume 78, pages291-303(1989).

\section{Cite this article as :}

Ibrahim M. Abou El Lei, Nuri M. Triki, Khaled M. Mezughi , "Characterization of Pure and Undefined Petroleum Fractions of Messla and Sarir Crude Oils of Libya Using Correlation Models", International Journal of Scientific Research in Science and Technology (IJSRST), Online ISSN : 2395-602X, Print ISSN : 2395-6011, Volume 7 Issue 6, pp. 194-211, November-December 2020. Available at doi : https://doi.org/10.32628/IJSRST207615 Journal URL : http://ijsrst.com/IJSRST207615 